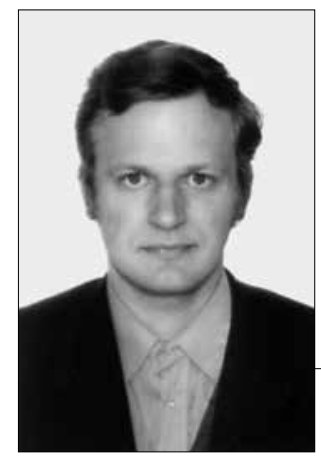

https://doi.org/10.24101/logos.2016.05

Gauta 20161007

\title{
VALDAS SELENIS
}

Lietuvos edukologijos universitetas

Lithuanian University of Educational Sciences

\section{ISTORIZMAS IR LIETUVIŲ TAUTINIO SAVITUMO PROBLEMA}

Historicism and Problem of Lithuanian National Distinction

\author{
SUMMARY
}

The article deals with the problem of Lithuanian national identity in Lithuanian professional historiography during first half of twentieth century. Historians of the first Republic of Lithuania (1918-1940) considered nationalism as negative thing, and historical science should keep a distance from political actualities. But the practical functions of such scholarship basically coincided with the tasks of modern Lithuanian nationalism. The history of the Grand Duchy of Lithuania was the primarily focus. It was necessity to give an answer to the "alien" Polish historiography. Although romanticism in contemporary Lithuanian historiography was criticized by historians of various creeds, there were two opinions about Lithuanian cultural distinction. The first suggested that pagan Lithuanian culture (folk arts, folklore and language) was the original expression of culture. The second suggested that during pre-Christian epoque no significant cultural artifacts had been created. Sometimes both of these opinions were supported by the same historians (A. Šapoka, Z. Ivinskis).

\section{SANTRAUKA}

Straipsnis skirtas nepriklausomos Lietuvos (1918-1940) istoriografijos santykiui su lietuvių tautos savitumo problema aptarti. Pagal praktines gyvenimo orientavimosi funkcijas tuometinių istorikų požiūris sutapo su nacionalinio istorizmo keliamais tikslais. Istorikams svarbiausia buvo ištirti politinę, pirmiausia Lietuvos Didžiosios Kunigaikštijos, istoriją ir duoti „atkirtį" kaimyninei „svetimujjų“ istoriografijai. Šios tendencijos neaplenkė ir kultūros istorijos - savo ruožtu stengtasi duoti atsaką lenkų istorikų tezėms. Lietuviškasis nacionalinis istorizmas, arba kritiškoji istoriografija, siekẻ atsiriboti nuo nepagristų istoriniais dokumentais teiginių, patoso, istorinių veikejuu garbinimo. Išsiskyrè dvi nuomonės dèl lietuvių kultūros savitumo: pirmoji teigè, kad pagoniškoji Lietuvos kultūra (tautodailè, tautosaka, kalba) buvusi savita kultūros išraiška, antroji - kad ikikrikščioniškuoju laikotarpiu Lietuvoje nebuvo sukurta tokių kultūros artefaktų, kuriuos galètu perimti kitos tautos. Abi šias nuomones kartais reiškè tie patys istorikai (A. Šapoka, Z. Ivinskis). 


\section{IVADAS}

XX a. pirmoje pusėje Europoje istorijos mokslas buvo plačiai naudojamas kaip politinis ginklas nacionaliniams interesams ginti. Pirmojo pasaulinio karo bei su juo susijusių konfliktu, taip pat ir ankstyvuju tautos karo istorijos epizodu atminties muziejai ikurti Latvijoje (Kara muzejs, 1919), Lenkijoje (Muzeum Wojska Polskiego, 1920), Baltarusijoje, Ukrainoje, Turkijoje ir Lietuvoje (Lietuvos karo muziejus, 1920, Vytauto Didžiojo karo muziejus, 1936) ${ }^{1}$. Šiose istaigose herojinis istorinis naratyvas buvo visuomenei pateiktas paveikia vizualiąa forma. Visuomenès istorinès atminties ir sąmonès formavimui buvo pasitelkti ir istoriku tekstai. Romantizmo ir istorizmo santykis „kuriant" tautą yra panašus i dvi to paties medalio puses. Leopoldo von Ranke's istorizmas (arba objektyvizmas) rèmèsi didžiųjų valstybių koncepcija, legitimizuojančia Vokietijos ekspansiją. Valdžios vertikalè pastarojoje vaidino pagrindini vaidmeni formuojant nacionalinę politinę santvarką ir istoriografiją. Anot žymaus istoriko postmodernisto Haydeno White'o, „,...Rankès metodas, ne vien tik naiviai induktyvus, bet visu pirma gristas prielaida, kad tauta yra vienintelis galimas (ir vienintelis trokštamas) socialinès organizacijos vienetas, ir įsitikinimu, kad dèl to tautinès grupès yra vieninteliai gyvybingi istorinio tyrinejjimo objektai." ${ }^{2}$

XIX a. pirmoje pusëje skaitančiųjų istorikų darbus išsilavinusių tautos atstovų dar buvo nedaug, net turint omenyje vokiečius ar prancūzus. Vèliau plečiantis inteligentijos sluoksniui, ju gausèjo. Nors visuomenės istorinè sąmonè selektyvi - ji atmeta tai, ką nori užmiršti, arba tai, kuo nenori tikèti, tačiau istorikai tikèjo savų darbų svarba. Kuriantis tautinei valstybei istorijos pavyzdžiai, faktai, vaizdiniai, veikèjai tampa itin svarbūs. Žymus vokiečių istorikas ir teoretikas Jörnas Rüsenas, apmąstęs identitetų kovas kultūros lauke, teigia, kad nèra tokios viešpatavimo formos, kuri, kad isiteisintų, nepasinaudotu istorija ${ }^{3}$. Pirmiausia tautos savimonès „žadinimui“" pirmosios inteligentijos atstovai ir ideologai pasitelkè romantinès istorijos vaizdinius, vèliau šią užduoti perèmè kritiškosios istorinès mokyklos atstovai. Anot čekų istoriko ir „mažujų tautų“ nacionalizmų tyrinètojo Miroslavo Hrocho, pagrindiniai veiksniai, darę i̇taką tautinių istoriju konstravimui, yra šie: 1) istoriko įsivaizdavimas, kokia buvo istorijos raida ir pirmiausia kas yra tauta; 2) istoriko supratimas, kas yra tautos interesai; 3) istorinè realybè ir šaltiniai, taip pat politine ir visuomenine dabarties situacija; 4) realiai egzistuojanti skaitytoju visuomenè; 5) tautinès istoriografijos tradicijos ${ }^{4}$.

Anot žymaus teoretiko Anthony D. Smitho, nacionalizmą sudaro keturi elementai: tam tikra vizija (kiekviena tauta apibrèžia savo narių tapatuma, nes jos specifinè kultūra formuoja individa, šitos kultūros raktas - istorija), kultūra, solidarumas ir politika ${ }^{5}$. Ernestas Gellneris nacionalizmo pobūdžiui Rytų Europoje paaiškinti pasitelkè ir geografini faktorių, tinkantį ir Lietuvos specifikai trečioje laiko juostoje etnografinei „fazei“ būdinga, kad kuriama nacionalinè ir valstybinè kultūra yra ne valstiečių kultūros antitezè, bet jos pagrindas. Liaudies kultūra čia panaudota įžiebti aukš- 
tają kultūra, žinoma, kiek standartizuota, „istorinès" ar "neistorinès" tautos statusas čia mažai ką reiškia - pavyzdžiui, čekai ar lietuviai gali žvelgti atgal i viduramžiu šlovę, o estai, baltarusiai ar slovakai to padaryti negali' . Dél baltarusių E. Gellneris nèra teisus - kai kurie ju žymūs veikejjai, pavyzdžiui, Vaclavas Lastouskis jau nuo XX a. pradžios Lietuvos Didžiąją Kunigaikštystę vadino Lietuvių-Baltarusių valstybe.

Šio straipsnio tyrimo objektas - nacionalizmo kaip vieno iš modernizmo epochos bruožų apraiškos nacionalinèje Lietuvos istoriografijoje valstybès atkūrimo / įkūrimo laikotarpiu. Tikslas ir uždaviniai: ištirti istoriografinį lietuviškajji istorinį naratyvą žymiausių istoriku darbuose ir juose pasitaikančias diskusijos dèl lietuvių tautos savitumo užuomazgas; atskleisti romantizmo ir nacionalizmo sampratas Lietuvos $X X$ a. pirmos pusès istoriografijoje.

Artimiausi šiam tyrimui yra vis gausiau pasirodantys Lietuvos istoriniu naratyvu ir istorinès atminties tyrimai bei diskusinio pobūdžio darbai. Vienas tokių - daug diskusijų sukèlusi filosofés Nerijos Putinaites knyga apie romantini istorini naratyvą ir Jono Basanavičiaus etnolingvistinį tautinès tapatybès mode$\mathrm{li}^{7}$, tačiau reiktų pažymèti, kad tuometinèje Lietuvos istoriografijoje buvo ir noras atsiriboti nuo romantinio diskurso, taip pat abejotina, ar J. Basanavičiaus laikysena buvo ",apolitiška“, nes jis neformaliai pritare kito "tautos daktaro" Jono Šliūpo politiniams tikslams. Svarbiu ir įdomių faktų atskleidè Dangiro Mačiulio darbai apie kultūros politiką ir istorinės atminties formavimą Lietuvoje tautininku valdymo laikotarpiu ${ }^{8}$. Roberto Šimkaus darbai naudingi ieškant Lietuvos ir Latvijos istoriografiniu konfliktu, galimybės palyginti konkuruojančias istorines atmintis ir naratyvus 9 . Paminètini ir tiesiogiai šio straipsnio temai artimi straipsniu rinkiniai: Lietuvos Didžiosios Kunigaikštijos tradicija ir paveldo „dalybos" (Vilnius, 2008), Lietuvos Didžiosios Kunigaikštijos tradicija ir tautiniai naratyvai (Vilnius, 2009). Alfredas Bumblauskas juose paskelbtuose straipsniuose akcentavo Zenono Ivinskio ir Adolfo Šapokos istorinių naratyvu sankirtas, pristate ir lenku, rusu, baltarusių, ukrainiečių tautinius naratyvus. Alvydas Nikžentaitis nedideliame leidinyje aptare Vytauto ir Jogailos įvaizdžių kūrimą tautiniame naratyve. Galima pritarti jo teiginiui, kad tarpukario laikotarpiu tautiniu istoriografiju kova buvo tipiškas reiškinys Europoje, nulėmęs ir istoriku pozicijas. Olga Mastianica monografijoje, skirtoje lietuviškojo moderniojo nacionalizmo požiūrio ị bajorijos vietą modernioje lietuvių tautoje formavimuisi ir raidai aptarti, pažymi, kad lietuviškojo nacionalizmo siekis įtraukti bajoriją i modernios lietuvių tautos formavimą išryškëjo jau "Aušros“" leidimo laikais ${ }^{10}$. Norèta legitimuoti etnografinès Lietuvos sampratą ir ją priešinti istorinio valstybingumo tradicijai. Aurelijus Gieda disertacijoje aptarè Lietuvos nacionalinès istoriografijos raidą 1904-1940 m. ir prièjo išvada, kad XX a. pirmame dešimtmetyje galime fiksuoti perejimą nuo istoriografinio pragmatizmo prie istorizmo ${ }^{11}$.

Visų užsienyje pasirodžiusių nacionalizmo ittaką nacionalinėms istoriografijoms nagrinëjančių publikacijų išvardin- 
ti čia dèl vietos stokos nèra galimybès, tačiau Lenkijoje istorikų kuriamus naratyvus analizavo Andrzejus F. Grabskis ${ }^{12}$, Lenkijos visuomenès istorinès sąmonès problemas - Jerzy Topolskis ${ }^{13}$. Paminètinas britų istorikas Johnas Breuilly, savo publikacijose analizuojantis nacionalistinị istoriografinį diskursą ${ }^{14}$. Paminètina ir 5 metus (2003-2008) veikusi Europos mokslo fondo (ESF) remiama tarptautine programa „Representations of the Past: The Writing of National Histories in 19th and 20th Century Europe", skirta Europos istorinių nacionalinių naratyvų tyrimams ir ju apibendrinimui. Šios programos apimtis -8 tomų studiju, straipsniu ir informacinių leidiniu serija, kurioje pristatomi Europos nacionaliniu naratyvų struktūros tyrimai, nacionalinių naratyvu izvairové Europoje.

Šio straipsnio šaltiniai $-X X$ a. Lietuvos istoriku straipsniai ir recenzijos, pasirodžiusios tuometinejje periodinejje spaudoje ir ju rankraščiai.

\section{NACIONALIZMO SAMPRATOS IR TAUTINIS NARATYVAS}

XIX a. pabaigoje-XX a. pradžioje vyko tautiniu istorinių naratyvų kūrimo procesas visoje Vidurio ir Rytu Europoje. Baltarusiai, lietuviai, lenkai, rusai, latviai, estai, t. y. „kaimynu“" tautos, įvairiu lygiu, priklausomai nuo valstybinio statuso, tuos naratyvus kūrè. Beje, XIX a. viduryje estai nesuvokè savęs kaip vieningos etninès grupès, vadinosi „maarahvas" - „kranto žmonès"15. Tautos savitumo bandyta ieškoti kovose su pavergëjais. Tarpukario Latvijoje daugeliui to meto latviu istoriku Latvijos istorija nuo XIII iki XIX a. buvo nesutaikoma latvių ir vokiečiu kova ir pagrindinis istorijos darbų motyvas - ieškoti ịrodymų, kad latviai Europos istorijoje taip pat suvaidino savo vaidmeni ${ }^{16}$. Istoriniai naratyvai tampa "svetimi“", kai ima konkuruoti. Čia reikia atkreipti dèmesí, kad ne visuomet nacionalinès istoriografijos profesionalizacija ir institucionalizacija sutapdavo su nacionalinès valstybès sukūrimu. Pavyzdžiu toli ieškoti nereikia pirmoji Lenkijos istorijos katedra ikurta 1869 m. Krokuvos universitete, gerokai anksčiau iki Lenkijos Respublikos nepriklausomybès paskelbimo, pirmoji Lietuvos istorijos katedra - tik $1922 \mathrm{~m}$. nepriklausomos Lietuvos universitete Kaune. Žinoma, tokị „,atsilikimą“ lėmè ne tik tai, kad Krokuva buvo Austrijos-Vengrijos, o ne Rusijos imperijos sudetyje, bet ir gerokai gausesnis "tautiškai susipratusios" inteligentijos sluoksnis. Lietuviu atveju analogiškas jos branduolys pradèjo burtis tik $1907 \mathrm{~m}$. įkūrus Lietuviu mokslų draugiją.

Nacionalizmas daugiausia būdingas pirmajai mokslinei istoriografijos paradigmai - istorizmui. Pažymètina, kad dèl paties istorijos mokslo Lietuvos istoriku nuomonès išsiskyrė nežymiai. A. Janulaitis, kuris tyrinëjo Lietuvos visuomenès istoriją „materialistiniu“ metodu, teigè, kad istorija toks pat mokslas kaip gamtos ir kiti mokslai, bet pats sau prieštaraudamas neigè, jog iš jo galima reikalauti objektyvumo, o grynas „,istoristas“ A. Šapoka savo paskaitų ivvade rašè, kad istorikas „ribojasi su menininku“, tik pastarasis nevaržomas tikrovès ${ }^{17}$. Nacionaliz- 
mo sąvoka turëjo ir turi negatyvų atspalvị, tačiau naratyvinių teorijų požiūriu Lietuvos istoriografijoje vyravo Didysis nacionalistinis pasakojimas. Be to, tautininkiškumas ir tautiškumas yra laikomas savaimine vertybe, kuriai neretai netaikoma nacionalizmo sąvoka ${ }^{18}$. Matyt, todèl Šapoka neigè ketvirtajame dešimtmetyje pasitaikiusius iš Lenkijos ar Vokietijos atklystančius kaltinimus lietuviškuoju nacionalizmu, nes, anot jo, „Tai yra tik svetimuju pagamintus akinius padejusio lietuvio žvilgsnis ị savo tautos praeiti...."19 1939 m. „Naujosios Romuvos" puslapiuose filosofas Antanas Maceina rašè, kad tautos pagrindas yra tautinè individualybè, kurios jungti sukuria rasè, gyvenamoji aplinka ir istorinis likimas. Jis teigè, kad kiekviena konkreti kultūra gali būti tiktai tautinè, o tautiškumas objektyviajame gyvenime susekamas tiktai iš kultūros laimejjimų: iš mokslo, meno, literatūros ir kt., todèl tautinèje valstybejje politiniai uždaviniai nublanksta prieš kultūrinius. Tautos objektyvizacija reiškiasi tik tautinès valstybės sukūrimu, ir kova su tautos kūno „skaldytojais svetimtaučių gaivalais" turi gilią prasmę ${ }^{20}$. Tuometinè nacistų valdoma Vokietija suaktyvino ivvairias kraštutines nacionalistines ir rasistinès idejas, kurios veikè ir žymujji filosofą ateitininką. Politinès situacijos nenuspejjamumas, jègos kulto patrauklumas skatino radikalumą ir akademiniame diskurse. Tačiau istorikai kitų Lietuvos tautų atžvilgiu tokių agresyvių minčių nereiškè, nors Šapoka tautinėms mažumoms ir taikè nemaloniai skambantị "prašaliečių“ epitetą ${ }^{21}$. Tokias mintis ribojo ir autoritarinis režimas, kas šiuo atveju laikytina pozityviąja cenzūra. Juozas Jakštas pagyrè humanišką A. Smeto- nos tautiškumą ir atskirame straipsnyje $\mathrm{e}^{22}$.

Iškilusis rusų egzilio atstovas Levas Karsavinas laikè kraštą (teritoriją), to krašto gyventojus (tautą) ir politinę-socialinę jų santvarką (valdžią) vieno individo, vienos esybès dalimis, būtinomis bet kuriai tautai, bet pažymèjo, kad „žinoma, tautą kuria ir bendras likimas, kraujas. Bet nereikia hitleriškai šito bendrojo kilimo perdèti, kad ir kaip masintų karštakošius nacionalistus Rassenthe-

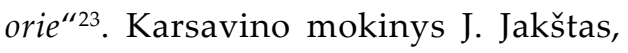
kuris ketvirtajame dešimtmetyje rašè "protautininkiškus“ straipsnius, istorijos rašymo tikslus susiejo su jo gyvenamo meto aktualijomis: „Paskiru istoriku tyrinejjimą sąlygoja vyraujanti aplinkos ideologija. Bendriausia tokia ideologija dabartiniam gyvenime yra tautiškumas. "24 Taigi atrodytu, kad alternatyvos tuometinei oficialiajame diskurse vyraujančiai ideologijai nebuvo. Paradoksalu, tačiau manau, galima teigti, jog Augustinas Voldemaras laikèsi prieštaringos nuomonès, nebūdingos nei istoristams, nei pozityvistams. Skaitydamas savo "daugiau filosofiška, negu istorišką" "Istoriškojo žinojimo teorijos ir metodologijos" kursą Lietuvos universiteto studentams, lygino istorijos mokslą su gamtos ir tiksliaisiais mokslais, visą kursą skyrè išaiškinti, kas yra mokslas, kokios yra žinojimo rūšys. Voldemaras prièjo išvadą: „Tas objektyvizmas yra tik miražas. Tokio objektyvizmo nèra nei Gamtoje, nei matematikoje nei kitur [...], matematikos formulè yra priedanga nežinojimo. “25 Taigi viskas yra reliatyvu ir subjektyvu. 1907 m. „Draugijoje“ recenzuodamas J. Totoraičio studiją apie karalių Mindaugą, pažymėjo: „Čia mus interesuoja ne tiek vidutinis, taip sakant, 
geografinis padejjimas, kiek kraštinis, t. y. koki kaimynai apsupe lietuvius ir koki buvo keliai, kurie jungè Lietuvą su kultūriniais centrais." Svarbiausiu keliu Voldemaras laikè kelią „,iš varingų (variagų) i graikus" ir nurodẻ Vasilijaus Kliučevskio darbus, įrodžiusius jo svarbą. Tai rodytu Voldemaro, kaip netradicinio istoriko, palankumą pozityvistinès krypties tematikai ir istoriografijai, gal net galejjusi sudaryti prielaidas „analü“ stiliaus alternatyvai tuo metu vyravusiam istorizmui $^{26}$. Tačiau rašydamas apie tautos istoriją jis nukrypdavo $\mathrm{i}$ istorizmo "stovyklą“, pavyzdžiui, 1921 m. „Mūsų Senovèje" publikuotoje Antano Aleknos Lietuvos istorijos vadovèlio recenzijoje rašè taip pat, kaip vėliau Šapoka, J. Matusas, P. Štuopis ir kiti nacionalinio istorizmo atstovai: „Bet mūsų istorija be galo susipynusi su mūsų kaimynų, rusų ir lenkų [...]. Jie dažniausiai net nepastebėdavo skirtumo tarp savo tautos ir lietuvių istorijos [...]. Tokiu būdu rusų ir lenkų tyrinejjimuose lietuviai savo valstybèj pranyksta ir tampa veik inamiais Lietuvoje. Mums gi lietuviams rūpi mūsų praeity kaip tik mūsų tautos likimas, o ne svetimų ją užkariautų gaivalų, arba svetimos įtekmès, kad ir žymios." Atskirti „,tikrus“ lietuvius nuo svetimu „gaivalų" nebuvo lengva.

Lenkų teisès istorikas Janas Adamusas, recenzuodamas Ivano Lappo darbą apie 1588 m. Lietuvos Statuta, atkreipe dèmesi, jog pastarasis iš anksto tvirtina, kad jau XVI-XVIII a. buvo lietuviškasrusiškas tautinis antagonizmas prieš lenkišką nacionalizmą. Šaltiniai, anot Adamuso, to nerodo, tai yra tikejjimo dalykas, iki kurio reikia ,pritraukti“ faktus. Lenkiškojo nacionalizmo dogmą jis perèmęs iš kitų rusų istorikų, būtent iš Matvejaus Liubavskio. Lietuvos separatizmas pasireiškia valstybiniu ir politiniu lygmeniu, bet ne tautiniu. Adomas Mickevičius galejo rašyti „Litwa ojczyzna moja" be baimès būti priskirtam prie lietuvių tautinių patriotų. Baigdamas recenziją J. Adamusas reziumuoja L. Ranke's stiliumi, kad nèra teisingo rusiško, lietuviško, lenkiško mokslo, teisingas mokslas yra tiesa, kuri yra viena, kaip ir mokslas yra vienas ${ }^{27}$. J. Adamusas recenzavo ir Šapokos darbą Lietuva ir Lenkija po 1569 metu unijos, ju valstybiniu santykiu bruožai, sukritikavo jo teigini, kad bajoriškoji teise kilo iš Lenkijos, todèl net lietuviai abi valstybes vadino Lenkija. Čia Adamusas recenzijoje retoriškai klausia Šapokos: „ar ir tie lietuviai, kurie nemokejo nè žodžio lietuviškai?" ${ }^{28}$ Šapoka aiškino, jog ši „painiava" atsirado todèl, kad abi valstybès buvo grynai luominès, o luomas (bajorija) buvo vienas ir turejjo bendru interesų bei reikalų, todèl turejjo bendrauti viena kalba [37, 295].

\section{LIETUVIŲ ISTORINIS TAUTINIS NARATYVAS IR KULTÜRINIO SAVITUMO PROBLEMA}

Pirmieji kultūros istorikai Lietuvoje buvo Juzefas Jaroševičius ir Simonas Daukantas. Dèl akivaizdžių istorijos darbų skirtumų nuo Daukanto ir gausaus rèmimosi istoriniais šaltiniais, platesnio tyrinètinų kultūros apraiškų supratimo Jaroševičius nelaikytinas romantinès pragmatinès-didaktinès istoriografijos 
atstovu, jis - prepozityvistinès krypties istorikas $^{29}$. Tačiau, nors ir kukliai, Daukantas panaudojo lietuvių tautosaką, kuria plačiau rèmėsi tautinio romantizmo kultūros istorikai-mėgèjai. Jų „vienintelis žymus kultūros istorijos reprezentantas", anot Z. Ivinskio, buvo Jonas Basanavičius, kurio įsteigtoji Lietuvių mokslo draugija iškèlè tikslą ištirti lietuvių tautą ir jos apgyventą kraštą.

XIX a. pabaigoje-XX a. pradžioje vyko ilgai trukęs persiorientavimas iš romantinès pasaulèžiūros ị istoristinę valstybinę-tautinę savivoką. Persiorientuoti nebuvo lengva. Leonas Wasilewskis rašè, kad lietuviais save laikè tie, kurie kalbèjo lietuviškai, ir tie „koroniarai“, kurie nemokèjo nè žodelio lietuviškai, bet gyveno Lietuvos provincijoje. Lietuviai gali susikalbèti tik su tautiečiais, o baltarusių kalbą supranta ir lenkas, ir rusas. Lietuvių tauta grynai valstietiška, bet skiriasi nuo baltarusių, kurie neturi nei inteligentijos, nei savos literatūros ${ }^{30}$. Inteligentija dalijosi i liberalią ir konservatyvią sroves. Pastarosios atstovo Maironio koncepcija artimesnė akademiniam istorijos mokslui negu Basanavičiaus ir buvo perimta nepriklausomybès laikų istoriografijos. Anot A. Bumblausko, tai natūralu, nes jis mokèsi, kad ir trumpai, Kijeve pas LDK istorijos tyrèją Vladimirą Antonovičių ir 1891 m. išleido Apsakymus apie Lietuvos praeiga, kurie 1906 m. virto Lietuvos istorija. Jos centre - nebe pagonybès laikai, o „kunigaikščių epocha" su Vytautu priekyje ${ }^{31}$. A. Giedos nuomone, Jono Mačiulio (Maironio) darbai užima išskirtinę vietą lietuviškų istorijos vadovèlių ir sintezių leidybos ištakose ${ }^{32}$.
Maironio darbą tęsè kitas dvasininkas - Antanas Alekna. Pastebejjęs, kad baltarusių mokslininkai Lietuvos kunigaikščių vardus kildina iš stačiatikiu šventujuu vardų, 1903 m. pasiūlè lietuviškus kunigaikščiu vardų variantus: Mindaugas, Gediminas, Algirdas, Kęstutis, Vitautas, Švitrigailè, Jogailè ${ }^{33}$.

Lenkų istorikas, filosofas ir savitos civilizacijų teorijos kūrëjas Feliksas Konecznis teigè, jog "Letuva“ tik nedidelè dalis „visos Lietuvos (Litvos)“, o 1922 m. Liucjanui Želigovskiui užèmus Vilnių, sukonkretino, kad tai tebuvusi Žemaitija. Kita vertus, F. Konecznis taip pat teigè, kad lenkai nevaldè Lietuvos, kuri iki $1791 \mathrm{~m}$. buvo nepriklausoma valstybè su atskira kariuomene, iždu, mokesčiais. Tai Lietuvos istorijos dalis. Lietuviška dinastija valdė Lenkija, todèl lenkiškų sąvokų lietuvių bajorija perèmė mažai ${ }^{34}$. Michailas Muravjovas buvo kolonizatorius, nes suteikè kankinystei už lenkiškumą šventumo prasmę lietuviškos bajorijos akyse, o tai reiškia, kad Lietuvą polonizavo ne Lenkija, o Rusija. Konecznis iškèlè klausimą: kokiai civilizacijai priklauso lietuviai, kurie lietuvišką patriotizmą grindžia neapykanta Lenkijai? Jo atsakymas, kad tai esąs turaniškasis - slaviškasis (maskvietiškas) modelis ${ }^{35}$.

Savo ruožtu lietuvių istorikai turèjo duoti ir atsakymą i klausimą, kur buvo Lituania propria. Petras Klimas 1917 m. rašè: „Tur būti nèra tokio lietuvio, kurs, apie Lietuvos plotą klausiamas, nemokètų kaip atsakyti [...]. Visa didžiulè Kauno gub., Palangos pajūris, Suvalkija, Vilniaus „rytai“ ir Gardino gubernijos kraštas - šit atsakymas, tai vadinamoji „Didžioji“" Lietuva [...] buvo lietuviai sve- 
timos tautos valstybeje, tarytum, be savosios žemés. "36 1919 m. Lietuvių mokslo draugijos išleistas Petro Klimo darbas Lietuviu senobės bruožai laikytinas vienu pirmujuc sintetinių kultūros istorijos darbų. P. Klimas sugebejjo kritiškai panaudoti šaltinius ir mokslinę literatūrą ir pateikti originalių išvadų. Diplomatinè tarnyba sutrukde jam parengti keliu tomų Lietuvos istorija, kurioje daugiausia dèmesio skirta kultūros istorijai. Jis minètame Vilniuje išleistame nedidelès apimties leidinyje rašè apie senovès lietuvių pastatus, remdamasis XVI a. kronikininkų žiniomis ir net išlikusia medžiaga (Juozo Tumo atrastas iš XVII a. išlikęs namas Telšių apskrityje). Aprašė prekybą, papročius, visuomenès struktūrą, ekonominius santykius, „būdą" (antropologini tipą), religiją.

Lietuvių istorikams nepriklausomos valstybės gyvavimo laikotarpiu, ypač tautininkų valdymo metais, ne kartą buvo iškilęs lietuvių kultūros savitumo klausimas. P. Klimo darbas ilgai nesulaukè tęsinio, nes kultūros istorija labiau pradèta tyrinèti tik valstybės gyvavimo paskutiniajame dešimtmetyje, o iki tol beveik visas dėmesys teko politinei - valstybès ir kunigaikščiu - istorijai. Politinè istorija nustumdavo ị šalį kultūros istorijos tyrimus. Tačiau nepriklausomoje Lietuvoje atskirais kultūros istorijos klausimais vis labiau domėtasi. Tai rodo A. Janulaičio, J. Totoraičio ir kitų istorikų darbai. Konstantinas Jablonskis ne tik išleido gerą trečdali XVI a. inventorių, bet ir paskelbẻ įvairių nuotrupų iš praeities kultūrinio gyvenimo. A. Šapoka skelbė straipsnių iš švietimo istorijos, Z. Ivinskis rinko medžiagą apie senąją lietuvių religiją.
J. Matusas pradejo nuosekliau tyrinèti materialinès kultūros istoriją. Dalis jo straipsnių, paremtų iki tol nenaudotais šaltiniais, 1939 m. publikuota nedidelès apimties leidinyje Lietuviu kultūra senais laikais. J. Matusas davė ryškius metmenis senojo lietuvių kultūrinio gyvenimo studijai. Minètų amžių lietuvių kultūros istorijos niekas sistemingiau netyrinejjo per visą šimtmeti. Rusų ir vokiečių istorikai paprastai domėdavosi politinemis institucijomis, kartais paliesdami vieną kitą kultūrinio gyvenimo klausimą (M. Liubavskis, I. Lappo). Lenkai sąmoningai žemino senąją lietuvių kultūrą (F. Papee, ypač A. Brückneris, Dzieje kultury polskiej, 1930-1935, autorius).

Besiimant Lietuvos kultūros istorijos tyrinejjimu, lietuvių istorikams reikejjo susipažinti ir su kaimynine istoriografija. Anot Rimvydo Petrausko, modernių lai$\mathrm{kuc} \mathrm{lietuvių} \mathrm{istorikų} \mathrm{koncepcijos} \mathrm{gimè} \mathrm{iš}$ aršios polemikos su lenkų istoriografija ne vienu atveju kaip savita lenkų darbų antitez $\dot{\mathrm{e}}^{37}$. Polonocentristas A. Brückneris, lietuvių pagonybę laikęs nekultūros pasireiškimu, Lenku kultūros istorijoje rašè, kad „pirmykštès“ Lietuvos kultūra buvo truputi menkesnè negu prūsų. Iš Lietuvos regionu Žemaitija buvo turtingiausia. Tačiau pagoniškoji kultūra negalëjo atsispirti krikščioniškajai rusų kultūrai, papročiams, raštui. „Lietuviškoje" kunigaikštystèje tikroji lietuviška žemè neužèmė nè vienos dešimtosios ploto, o patys lietuviai, išskyrus jų bajorus, valstybiniame gyvenime nieko nereiškè ${ }^{38}$. Jau Jogailos sūnūs lietuviškai nemokėjo kalbėti. Lietuviškai kalbejjo tik valstietis kaime, perimdamas ir daug rusizmų. Saksų dinastijos laikais XVIII a. 
lietuvių kalba žydèjo tik Žemaitijoje, o iš Vilniaus išnyko visiškai, tad jèzuitai nustojo sakyti pamokslus lietuviškai, tik Prūsijoje buvo kuriama grožinè literatūra (K. Donelaičio „Metai“ ir kt.). Su šiais A. Brücknerio teiginiais, lietuvių istorikai nesutiko. A. Brückneris kanceliarinèje rašto kalboje radęs tik "porą" lietuviškų žodžių, o iš tiesų ten jų yra pustrečio šimto. Lenkų kultūros istorikų teiginiai

\section{Literatūra ir nuorodos}

${ }^{1}$ Lutz Raphael, Historians and the First World War. Atlas of European Historiography. The Making of a Profession 1800-2005. Palgrave Macmillan, 2010, p. 35.

${ }^{2}$ Hayden White, Metaistorija: istorine vaizduote XIX amžiaus Europoje. Vilnius, 2003, p. 204.

3 Jörn Rüsen, Istorika. Vilnius, 2007, p. 48.

${ }^{4}$ Miroslav Hroch, Małe narody Europy. Wrocław, 2003, s. 130.

5 Anthony D. Smith, Nacionalizmas XX amžiuje. Vilnius: Pradai, 1994, p. 11.

${ }^{6}$ Ernest Gellner, Encouters with Nationalism. Blackwell, 1995, p. 191.

7 Nerija Putinaitè. Šiaurés Atènu tremtiniai. Lietuviškosios tapatybès paieškos ir Europos vizijos XX a. Vilnius: Aidai, 2004.

8 Dangiras Mačiulis. Valstybès kultūros politika Lietuvoje 1927-1940 metais. Vilnius, 2005; Dangiras Mačiulis. Apie dvi propagandines kampanijas XX a. Lietuvoje. Inter-studia humanitatis, 2009, nr. 9, p. 119-138.

${ }_{9}$ Robertas Šimkus, Istoriografinių konfliktų prielaidos: konkuruojančios istorinės atmintys tarpukario Latvijoje, Acta humanitarica universitatis Saulensis. T. 9, 2009, p. 55-72.

${ }^{10}$ Olga Mastianica, Bajorija lietuviu tautiniame projekte (XIX a. pabaiga - XX a. pradžia). Vilnius: Lietuvos istorijos institutas, 2016, p. 171-173.

11 Aurelijus Gieda, Istoriografija ir visuomene: istorika, istoriko profesijos ir istorinès kultūros aspektai Lietuvoje 1904-1940 m. Daktaro disertacija. Vilnius, 2013.

12 Andrzej F. Grabski, Zarys historii historiografii polskiej. Poznań, 2003.

13 Jerzy Topolski, Studia nad świadomością historyczna polaków. Poznań, 1994. nebuvo priimtini lietuviams. Z. Ivinskis prièjo išvada, artimą ir A. Šapokai, kad ,toji pagonių lietuvių XIII, XIV, XV amž. kultūra nèra toki nyki ir skurdi, kaip ją vaizdavo svetimtaučiai kronistai ir kartais dar vaizduoja svetimi istorikai. Ji, tiesa, neimponavo pirmu pažvelgimu savo formomis. Bet ji buvo turtinga savita, tiek materijalinio, tiek dvasinio gyvenimo apraiškose “39.

${ }^{14}$ John Breuilly, Nationalism and historians: some reflections. The formations on nationalist historiographical discourse. Norton, Claire (ed.), Nationalism, historiography and the (re)construction of the past. New Academia Publishing, Washington DC, 2007.

15 Jörg Hackmann, Narrating the Building of a 'Small Nation'. Divergence and Convergence in the Historiography of Estonian "National Awakening" 1868-2005. Nationalizing the Past. Historians as Nation Builders in Modern Europe. Edited by S. Berger and Ch. Lorenz. Palgrave Macmillan, 2010, p. 170-192.

${ }^{16}$ Robertas Šimkus, Istoriografiniu konfliktų prielaidos: konkuruojančios istorinės atmintys tarpukario Latvijoje, p. 63.

17 Adolfas Šapoka, Vazu periodo Lietuva, universitete skaitytas Lietuvos istorijos (nuo $1587 \mathrm{iki}$ 1717 metų) kursas. 1933-IX. LMAVB RS, f. 233-10, 1. 1-2.

18 Alfredas Bumblauskas, Lietuvos Didžioji Kunigaikštija ir jos tradicija. Vilnius, 2010, p. 293.

19 Adolfas Šapoka, Aisčių kilmių bei jų tarpusavio santykių aiškinimas mokykloje. Tautos mokykla, 1937, nr. 1, p. 7.

${ }^{20}$ Antanas Maceina, Raštai. T. XII. Socialine ir politine filosofija. Vilnius: Margi raštai, 2007, p. 5961.

${ }^{21}$ Adolfas Šapoka, Iš kur atsirado Lietuvoje rusų. Šviesos keliai, 1934, nr. 7, p. 427.

22 Juozas Jakštas, Humaniškas Smetonos tautiškumas. Vairas, 1934, t. XII, nr. 8-9, p. 105-109.

${ }^{23}$ Leonas Karsavinas, Valstybė ir demokratijos krizè. Židinys, 1934, nr. 5-6, p. 433-451.

24 Juozas Jakštas, Istorijos mokslas ir gyvenimas. Vairas, 1932, nr. 10, p. 88. 
25 Paskaitų „Istorijos žinojimo teorija ir metodologija" rankraštis saugomas Lietuvos centriniame valstybès archyve (toliau - LCVA), f. 378, ap. 13, b. 7. Šiose paskaitose atsispindi ir metais anksčiau A. Voldemaro parengtas tekstas „Universitetas ir mokslas", kuris publikuotas 1925 m. Lietuvos universiteto Humanitarinių mokslų fakulteto raštų pirmoje knygoje (p. 123-131).

26 Aurelijus Gieda, Augustinas Voldemaras: intelektualinès biografijos eskizas ir kai kurie tarpdisciplininės orientacijos pavyzdžiai. Sociologija. Mintis ir veiksmas, 2013, nr. 2 (33), p. 172-173.

27 Jan Adamus. Rec. LAPPO, Ivan. Litovskij statut 1588 goda. T. I. Issledovanije. Kaunas, 1934. Ateneum Wileńskie, R. 11, 1936, s. 509-516.

28 Jan Adamus. Rec. A. Šapoka, Lietuva ir Lenkija po 1569 metuc unijos... Kaunas, 1938. Ateneum Wileńskie. R. 13, 1938, s. 318.

29 Tai pripažǐsta net ir tyrinètojai, tradiciškai J. Jaroševičiaus darbus analizuojantys romantizmo istoriografijos kontekste, žr.: Vytautas Berenis, Lietuvos istorija tarp Apšvietos ir romantizmo. Apšvietos ir romantizmo kryžkelèse. Filosofijos kryptys ir kontroversijos Lietuvoje XVIII a. pabaigoje pirmoje XIX a. pusèje. Vilnius, 2008, p. 220.

30 Leon Wasilewski, Litwa $i$ jej ludy. Warszawa, 1907, s. 9-10.
31 Alfredas Bumblauskas, Lietuvos Didžioji Kunigaikštija ir jos tradicija, p. 217.

32 Aurelijus Gieda, Istoriografija ir visuomene, p. 337.

33 Antanas Kurietis (Alekna). Kuo vardu buvo didieji Lietuvos kunigaikščiai, Dirva-Žinynas, 1903, balandis, nr. 7, p. 91-98.

34 Feliks Koneczny, Polskie logos a ethos. Roztrzasanie o znaczeniu i celu Polski. T. I. Poznań-Warszawa, 1921, s. 7.

35 Vengrų mokslininkai - atvirkščiai, siejo vengrus, suomius ir mongolus su tiurkų tautomis į etnologini „turaniškajji elementą" (Turanas - vietovè Centrinèje Azijoje), kaip priešstatą panslavizmui. Anthony D. Smith, Nacionalizmas XX amžiuje. Vilnius: Pradai, 1994.

36 Petras Klimas, Lietuva. Jos gyventojai ir sienos. Vilnius, 1917.

37 Rimvydas Petrauskas, Zenonas Ivinskis ir Henrykas Łowmiańskis: pokyčiai tarpukario medievistikoje Kaune ir Vilniuje. Lietuvos Didžiosios Kunigaikštijos tradicija ir tautiniai naratyvai. Vilnius, 2009, p. 225-237.

38 Aleksander Brückner, Dzieje kultury polskiej. T. I (reprint). Warszawa, 1991.

39 Zenonas Ivinskis, Senosios lietuvių kultūros problemos (pagal rašytus šaltinius). Naujoji Romuva, 1937, nr. 4-5, p. 93-99.

B. d. 